\title{
Ten New Species of Legionella
}

DON J. BRENNER, ${ }^{1 *}$ ARNOLD G. STEIGERWALT,${ }^{1}$ GEORGE W. GORMAN,${ }^{1}$ HAZEL W. WILKINSON ${ }^{1}$ WILLIAM F. BIBB, ${ }^{1}$ MEREDETH HACKEL, ${ }^{2}$ RICHARD L. TYNDALL, ${ }^{3}$ JOYCE CAMPBELL, ${ }^{4} \mathrm{JAMES}^{\mathrm{C}}$. FEELEY, ${ }^{1}$ W. LANIER THACKER, ${ }^{1}$ PETER SKALIY,${ }^{1}$ WILLIAM T. MARTIN,${ }^{1}$ BONNIE J. BRAKE, ${ }^{1}$ BARRY S. FIELDS, ${ }^{1}$ HAROLD V. MCEACHERN, ${ }^{1}$ AND LINDA K. CORCORAN ${ }^{1}$

Division of Bacterial Diseases, Center for Infectious Diseases, Centers for Disease Control, Atlanta, Georgia $30333^{1}$; Pathology Department, University Hospital, University of Michigan, Ann Arbor, Michigan 48109²; Environmental Sciences Division, Department of Zoology, University of Tennessee, Knoxville, Tennessee 37916 ${ }^{3}$; and Office of Public Health Laboratories and Epidemiology, Department of Social and Health Services, Seattle, Washington $98104^{4}$

Ten new Legionella species were characterized on the basis of biochemical reactions, antigens, cellular fatty acids, isoprenoid quinones, and deoxyribonucleic acid relatedness. Nine of the new species were isolated from the environment, and one, Legionella hackeliae, was isolated from a bronchial biopsy specimen obtained from a patient with pneumonia. The species all exhibited the following biochemical reactions typical of the legionellae: growth on buffered cysteine-yeast extract agar, but not on blood agar; growth requirement for cysteine; gram negative; nitrate negative; urease negative; nonfermentative; catalase positive; production of a brown pigment on tyrosine-containing yeast extract agar; liquefaction of gelatin; and motility. Legionella spiritensis was weakly positive for hydrolysis of hippurate; the other species were hippurate negative. Legionella cherrii, Legionella steigerwaltii, and Legionella parisiensis exhibited bluish white autofluorescence. Legionella rubrilucens and Legionella erythra exhibited red autofluorescence. The other species, $L$. spiritensis, $L$. hackeliae, Legionella maceachernit, Legionella jamestowniensis, and Legionella santicrucis did not autofluoresce bluish white or red. All species had cellular fatty acid contents qualitatively similar to those of previously described legionellae and had major amounts of ubiquinones with more than 10 isoprene units in the side chains. Each new species was serologically distinct from previously described Legionella species. As determined by the hydroxyapatite method at $60^{\circ} \mathrm{C}$, two strains of $L$. maceachernii were $100 \%$ related, and four strains of $L$. cherrii were 94 to $99 \%$ related. The other new species were represented by single strains. The levels of relatedness of the new species to each other and to previously described legionellae ranged from 1 to $67 \%$. $L$. maceachernii, $L$. jamestowniensis, and $L$. hackeliae were less than $25 \%$ related to other species. $L$. rubrilucens and $L$. erythra, and two red-autofluorescing species, were about $60 \%$ interrelated. $L$. spiritensis (a non-autofluorescing species) was $34 \%$ related to $L$. rubrilucens. $L$. santicrucis was $64 \%$ related to Legionella sainthelensi. The three bluish white-autofluorescing species, L. parisiensis, L. cherrii, and $L$. steigerwaltii, were most closely related to other bluish white-autofluorescing species, especially Legionella bozemanii, Legionella dumoffi, Legionella gormanii, and "Legionella anisa"' (35 to 67\%).

A total of 221 cases of pneumonia resulting in 34 deaths occurred during an epidemic at the American Legion Convention in Philadelphia, $\mathrm{Pa}$., in $1976(22,23)$. After a massive investigation of this epidemic, the etiological agent of the so-called Legionnaires disease was finally isolated by McDade et al. (36). This organism was shown to be a bacterium that was phenotypically unique, whose deoxyribonucleic acid (DNA) was unrelated to the DNAs of all other species tested $(10-12,45)$. Therefore, it was classified in a new genus and species, Legionella pneumophila, in the new family Legionellaceae (10). L. pneumophila was subsequently shown to be a major cause of both pneumonia and an acute, self-limiting febrile disease called Pontiac fever (31). The public health significance of Legionnaires disease stimulated many intense investigations. It was soon learned that L. pneumophila had first been isolated in 1947 (35; E. B. Jackson, T. T. Crocker, J. E. Smadel, Bacteriol. Proc., p. $119,1952)$. We now recognize at least 10 serogroups in $L$. pneumophila $(2,4,19,38,39$; W. F. Bibb and R. M. McKinney, unpublished data). L. pneumophila strains were isolated from patients with pneumonia and from the environment.

Strains that resembled L. pneumophila but differed in one or more phenotypic characteristics were called Legionellalike organisms. Representative strains of Legionella-like

\footnotetext{
* Corresponding author.
}

organisms were studied biochemically, serologically, chemically for total cellular fatty acids, and by DNA relatedness. New species were proposed, as indicated by these data, with a present total of 12 named species. Legionella bozemanii $(6$, $9,27)$ was first isolated in 1959 and Legionella micdadei $(27$, $28,48,50$ ) was first isolated in 1943; both of these species have been isolated from patients with pneumonia. L. micdadei has also been isolated from human blood and from water and is commonly referred to as the Pittsburgh pneumonia agent (48). Legionella dumoffii was isolated first from water and later from human lung tissue $(9,33)$. Legionella gormanii $(18,41)$ was isolated from water, but serological evidence implicated it as another agent of Legionnaires disease. Legionella longbeachae (37) has only been isolated from humans, with strains of this species falling into two serogroups $(3,37)$. Legionella jordanis has been implicated in human pneumonia by indirect fluorescent antibody reactions with human sera (15) and was recently isolated from human lung tissue (51); it has also been isolated from water and sewage. Legionella oakridgensis (47) and Legionella sainthelensi (14) were isolated from water and have not been isolated from or implicated in cases of human pneumonia. Legionella wadsworthii (19) was isolated from a patient with pneumonia. Legionella feeleii was isolated from an industrial water source in a factory where an outbreak of Pontiac fever occurred (29); it was not isolated from patients in this outbreak, but serological evidence indicated that $L$. feeleii was the causative agent. L. feeleii was also recently isolated 
TABLE 1. Legionella strains

\begin{tabular}{|c|c|c|c|c|c|}
\hline Strain & Source & Location & Method ${ }^{\prime \prime}$ & Isolated by: & $\begin{array}{c}\mathrm{G}+\mathrm{C} \text { content } \\
(\mathrm{mol} \%)\end{array}$ \\
\hline $\begin{array}{l}\text { L. pneumophila } \\
\text { Philadelphia } 1^{\mathrm{T}} \\
(=\text { ATCC } \\
\left.33152^{\mathrm{T}}\right)\end{array}$ & $\begin{array}{l}\text { Lung tissue, human } \\
\text { pneumonia }\end{array}$ & $\begin{array}{l}\text { Philadelphia, } \\
\text { Pa. }\end{array}$ & Guinea pig $\rightarrow$ egg $\rightarrow$ MHIH & $\begin{array}{l}\text { J. E. McDade and } \\
\text { R. E. Weaver ( } 28 \\
\text { February 1977) }\end{array}$ & $39(10), 39(4)^{b}$ \\
\hline $\begin{array}{l}\text { L. bozemanii } \\
\text { WIGA }^{\mathrm{T}} \\
\left(=\text { ATCC }^{-}\right. \\
\left.33217^{\mathrm{T}}\right)\end{array}$ & Lung tissue, human & $\begin{array}{l}\text { Key West, } \\
\text { Fla. }\end{array}$ & Guinea pig $\rightarrow \mathrm{egg} \rightarrow \mathrm{CYE}$ & $\begin{array}{l}\text { F. M. Bozeman } \\
\text { (G. A. Hébert) } \\
1957 \text { (25 May 1979) }\end{array}$ & $43(35), 41(13)$ \\
\hline $\begin{array}{l}\text { L. micdadei } \\
\text { TATLOCK } \\
(=\text { ATCC } \\
\left.33218^{\mathrm{T}}\right)\end{array}$ & Blood, human & $\begin{array}{l}\text { Fort Bragg, } \\
\text { N.C. }\end{array}$ & $\mathrm{Egg} \rightarrow \mathrm{CYE}$ & $\begin{array}{l}\text { H. Tatlock } \\
\text { (G. A. Hébert) } \\
1943 \text { (25 May 1979) }\end{array}$ & $44(4), 41$ \\
\hline $\begin{array}{l}\text { L. dumoffii NY-23 } \\
(=\text { ATCC } \\
\left.33279^{\mathrm{T}}\right)\end{array}$ & Water, cooling tower & $\begin{array}{l}\text { New York, } \\
\text { N.Y. }\end{array}$ & Guinea pig $\rightarrow$ egg $\rightarrow$ CYE & $\begin{array}{l}\text { G. W. Gorman } \\
\text { (6 October 1978) }\end{array}$ & $41(13), 42$ \\
\hline $\begin{array}{l}\text { L. gormanii LS-13 }{ }^{\mathrm{T}} \\
(=\text { ATCC } \\
\left.33297^{\mathrm{T}}\right)\end{array}$ & Soil, creek bank & Atlanta, Ga. & Guinea pig $\rightarrow$ egg $\rightarrow$ CYE & $\begin{array}{l}\text { G. W. Gorman } \\
\text { (1 December 1978) }\end{array}$ & $41(13), 41$ \\
\hline $\begin{array}{l}\text { L. longbeachae } \\
\text { Long Beach } 4^{\mathrm{T}} \\
(=\text { ATCC } \\
\left.33462^{\mathrm{T}}\right)\end{array}$ & $\begin{array}{l}\text { Transtracheal aspirate, } \\
\text { human pneumonia (fatal) }\end{array}$ & $\begin{array}{l}\text { Long Beach, } \\
\text { Calif. }\end{array}$ & Direct plating on CYE & $\begin{array}{l}\text { R. Porschen } \\
\text { (10 April 1980) }\end{array}$ & 40 \\
\hline $\begin{array}{l}\text { L. jordanis } \\
\text { BL-540 } \\
(=\text { ATCC } \\
\left.33623^{\mathrm{T}}\right)\end{array}$ & Water, river & $\begin{array}{l}\text { Bloomington, } \\
\text { Ind. }\end{array}$ & Guinea pig $\rightarrow$ egg $\rightarrow$ CYE & $\begin{array}{l}\text { G. W. Gorman } \\
\text { (1 September 1978) }\end{array}$ & 45 \\
\hline $\begin{array}{l}\text { L. oakridgensis } \\
\text { Oak Ridge } 10^{\mathrm{T}} \\
(=\text { ATCC } \\
\left.33761^{\mathrm{T}}\right)\end{array}$ & Water, cooling tower & Pennsylvania & Guinea pig $\rightarrow \mathrm{CYE}$ & $\begin{array}{l}\text { R. L. Tyndall, } \\
\text { C. B. Duncan, and } \\
\text { E. L. Domingue } \\
\text { (April 1981) }\end{array}$ & $45(47)$ \\
\hline $\begin{array}{l}\text { L. wadsworthii } \\
81-716^{\mathrm{T}} \\
(=\mathrm{ATCC} \\
\left.33877^{\mathrm{T}}\right)\end{array}$ & Sputum, human pneumonia & $\begin{array}{l}\text { Los Angeles, } \\
\text { Calif. }\end{array}$ & $\begin{array}{l}\text { Direct plating on } \\
\text { selective BCYE }\end{array}$ & $\begin{array}{l}\text { P. H. Edelstein } \\
\text { (23 November } \\
1981)\end{array}$ & $42(19)$ \\
\hline $\begin{array}{l}\text { L. feeleii } \\
\text { WO-44C-C3 } \\
(=\text { ATCC } \\
\left.35072^{\mathrm{T}}\right)\end{array}$ & Water & $\begin{array}{l}\text { Windsor, } \\
\text { Canada }\end{array}$ & $\begin{array}{l}\mathrm{AT} \text {, direct plating on } \\
\mathrm{BCYE}+\mathrm{AB}\end{array}$ & $\begin{array}{l}\text { G. W. Gorman } \\
\text { (August 1981) }\end{array}$ & $46(29)$ \\
\hline $\begin{array}{l}\text { L. sainthelensi } \\
\text { Mount Saint } \\
\text { Helens } 4^{\mathrm{T}} \\
(=\text { ATCC } \\
\left.35248^{\mathrm{T}}\right)\end{array}$ & Water, spring & $\begin{array}{l}\text { Mount Saint } \\
\text { Helens, } \\
\text { Wash. }\end{array}$ & Direct plating on $\mathrm{BCYE}$ & $\begin{array}{l}\text { J. Campbell and } \\
\text { S. Eng (April 1981) }\end{array}$ & $41(14)$ \\
\hline $\begin{array}{l}\text { "L. anisa" } \\
\text { WA-316-C3 } \\
(=\text { ATCC } \\
\left.35292^{\mathrm{T}}\right)\end{array}$ & Hot water, sink & $\begin{array}{l}\text { Los Angeles, } \\
\text { Calif. }\end{array}$ & $\begin{array}{l}\text { AT, direct plating on } \\
\text { CYE }\end{array}$ & $\begin{array}{l}\text { G. W. Gorman } \\
\text { (22 April 1981) }\end{array}$ & $42^{c}$ \\
\hline $\begin{array}{l}\text { L. maceachernii } \\
\text { PX-1-G2-E2 } \\
(=\text { ATCC } \\
\left.35300^{\mathrm{T}}\right)\end{array}$ & $\begin{array}{l}\text { Water, home evaporator- } \\
\text { cooler }\end{array}$ & $\begin{array}{l}\text { Phoenix, } \\
\text { Ariz. }\end{array}$ & Guinea pig $\rightarrow$ egg $\rightarrow$ CYE & $\begin{array}{r}\text { G. W. Gorman } \\
(9 \text { July 1979) }\end{array}$ & 43 \\
\hline $\begin{array}{l}\text { L. maceachernii } \\
\text { SC-73-C2 }\end{array}$ & Potable water cistern & $\begin{array}{l}\text { St. Thomas, } \\
\text { V.l. }\end{array}$ & $\begin{array}{l}\text { AT, direct plating on } \\
\text { CYE }\end{array}$ & $\begin{array}{l}\text { G. W. Gorman } \\
\text { (24 April 1982) }\end{array}$ & 41 \\
\hline $\begin{array}{l}\text { L. jamestowniensis } \\
\text { JA-26-G1-E2 }{ }^{\mathrm{T}} \\
(=\mathrm{ATCC} \\
\left.35298^{\mathrm{T}}\right)\end{array}$ & Wet soil & $\begin{array}{l}\text { Jamestown, } \\
\text { N.Y. }\end{array}$ & Guinea pig $\rightarrow \mathrm{egg} \rightarrow \mathrm{CYE}$ & $\begin{array}{l}\text { G. W. Gorman } \\
\text { (12 December } \\
\text { 1979) }\end{array}$ & 42 \\
\hline $\begin{array}{l}\text { L. rubrilucens } \\
\text { WA-270A-C2 } \\
(=\text { ATCC } \\
\left.35304^{\mathrm{T}}\right)\end{array}$ & Tap water & $\begin{array}{l}\text { Los Angeles, } \\
\text { Calif. }\end{array}$ & $\begin{array}{l}\text { AT, direct plating on } \\
\text { CYE }\end{array}$ & $\begin{array}{l}\text { G. W. Gorman } \\
\text { (10 June 1980) }\end{array}$ & 52 \\
\hline $\begin{array}{l}\text { L. erythra } \\
\text { SE-32A-C8 } \\
(=\text { ATCC } \\
\left.35303^{\mathrm{T}}\right)\end{array}$ & Water, cooling tower & $\begin{array}{l}\text { Seattle, } \\
\text { Wash. }\end{array}$ & $\begin{array}{l}\text { AT, direct plating on } \\
\text { BCYE }\end{array}$ & $\begin{array}{l}\text { G. W. Gorman } \\
\text { (19 January 1981) }\end{array}$ & 51 \\
\hline $\begin{array}{l}\text { L. hackeliae } \\
\text { Lansing } 2^{\mathrm{T}} \\
(=\text { ATCC } \\
\left.35250^{\mathrm{T}}\right)\end{array}$ & $\begin{array}{l}\text { Bronchial biopsy, human } \\
\text { pneumonia }\end{array}$ & $\begin{array}{l}\text { Ann Arbor, } \\
\text { Mich. }\end{array}$ & Direct plating on $\mathrm{BCYE}$ & $\begin{array}{l}\text { M. Hackel } \\
\quad \text { (21 July 1981) }\end{array}$ & 40 \\
\hline
\end{tabular}


TABLE 1-Continued

\begin{tabular}{|c|c|c|c|c|c|}
\hline Strain & Source & Location & Method $^{a}$ & Isolated by: & $\begin{array}{c}\mathrm{G}+\mathrm{C} \text { content } \\
(\mathrm{mol} \mathrm{\%})\end{array}$ \\
\hline $\begin{array}{l}\text { L. spiritensis } \\
\text { Mount Saint } \\
\text { Helens } 9^{\mathrm{T}} \\
(=\text { ATCC } \\
\left.35249^{\mathrm{T}}\right)\end{array}$ & Water, lake & $\begin{array}{l}\text { Spirit Lake, } \\
\text { Wash. }\end{array}$ & Direct plating on $\mathrm{BCYE}$ & $\begin{array}{l}\text { J. Campbell } \\
\text { (23 August 1981) }\end{array}$ & 46 \\
\hline $\begin{array}{l}\text { L. parisiensis } \\
\text { PF-209C-C2 } \\
(=\text { ATCC } \\
\left.35299^{\mathrm{T}}\right)\end{array}$ & Water, cooling tower & Paris, France & $\begin{array}{l}\mathrm{AT} \text {, direct plating on } \\
\mathrm{CYE}+\mathrm{AB}\end{array}$ & $\begin{array}{l}\text { G. W. Gorman } \\
\text { (9 September 1981) }\end{array}$ & 42 \\
\hline $\begin{array}{l}\text { L. cherrii ORW } \\
(=\mathrm{ATCC} \\
\left.35252^{\mathrm{T}}\right)\end{array}$ & Water, thermally altered & Minnesota & Guinea pig $\rightarrow \mathrm{CYE}$ & $\begin{array}{l}\text { R. L. Tyndall and } \\
\text { C. B. Duncan } \\
\text { (8 January 1982) }\end{array}$ & 40 \\
\hline L. cherrii ORB & Water, thermally altered & Minnesota & Guinea pig $\rightarrow$ CYE & $\begin{array}{l}\text { R. L. Tyndall and } \\
\text { C. B. Duncan } \\
\text { (8 January 1982) }\end{array}$ & 40 \\
\hline L. cherrii ORZ & Water, thermally altered & Minnesota & Guinea pig $\rightarrow \mathrm{CYE}$ & $\begin{array}{l}\text { R. L. Tyndall and } \\
\text { C. B. Duncan } \\
\text { (8 January 1982) }\end{array}$ & 39 \\
\hline L. cherrii SC-65-C3 & Potable water cistern & $\begin{array}{l}\text { St. Croix, } \\
\text { V.I. }\end{array}$ & $\begin{array}{l}\text { AT, direct plating on } \\
\text { CYE }\end{array}$ & $\begin{array}{l}\text { G. W. Gorman } \\
\text { (21 March 1982) }\end{array}$ & \\
\hline $\begin{array}{l}\text { L. steigerwaltii } \\
\text { SC-18-C } 9^{\mathrm{T}} \\
(=\text { ATCC } \\
\left.35302^{\mathrm{T}}\right)\end{array}$ & Tap water & $\begin{array}{l}\text { St. Croix, } \\
\text { V.I. }\end{array}$ & $\begin{array}{l}\text { AT, direct plating on } \\
\text { CYE + AB }\end{array}$ & $\begin{array}{l}\text { G. W. Gorman } \\
\text { (10 March 1982) }\end{array}$ & 40 \\
\hline $\begin{array}{l}\text { L. santicrucis } \\
\text { SC-63-C7 } \\
\left(=\mathrm{ATCC}^{\mathrm{T}}\right. \\
\left.35301^{\mathrm{T}}\right)\end{array}$ & Tap water & $\begin{array}{l}\text { St. Croix, } \\
\text { V.I. }\end{array}$ & $\begin{array}{l}\mathrm{AT}, \text { direct plating on } \\
\mathrm{CYE}+\mathrm{AB}\end{array}$ & $\begin{array}{l}\text { G. W. Gorman } \\
\text { (21 March 1982) }\end{array}$ & 38 \\
\hline
\end{tabular}

${ }^{a}$ MHIH, Mueller-Hinton agar supplemented with IsoVitaleX and hemoglobin; selective BCYE, BCYE agar supplemented with $0.1 \%$ alpha-ketoglutarate, $4 \mu \mathrm{g}$ of cefamandole per $\mathrm{ml}, 80 \mu \mathrm{g}$ of polymyxin B per ml, and $80 \mu \mathrm{g}$ of anisomycin per $\mathrm{ml} ; \mathrm{AB}$, supplemented with $0.5 \mu \mathrm{g}$ of vancomycin per ml, $4 \mu \mathrm{g}$ of cephalothin per $\mathrm{ml}$, and $16 \mu \mathrm{g}$ of colistin per $\mathrm{ml} ; \mathrm{AT}$, acid treatment.

${ }^{b}$ The numbers in parentheses are reference numbers.

c Data from Gorman et al., in press.

from human sputum (51). "Legionella anisa" was isolated from potable water in two hospitals and from water in a cooling tower (G. W. Gorman, J. C. Feeley, A. G. Steigerwalt, P. H. Edelstein, C. W. Moss, and D. J. Brenner, Appl. Environ. Microbiol., in press). Serological studies to assess its possible role in human infection have not been done.

In this report, we summarize the data used to characterize additional legionellae, and we propose names for 10 new species; 9 of these were isolated from the environment, and 1 was isolated from a patient with pneumonia.

\section{MATERIALS AND METHODS}

Bacterial strains. The strains used in this study are listed in Table 1. They included the type strains of the 12 previously described Legionella species and the type strains of the 10 new species described in this paper. American Type Culture Collection numbers are given for all type strains. Strains of the new species were isolated by one of the following methods (Table 1): (i) direct plating of concentrated water samples or bronchial biopsy material onto charcoal-yeast extract (CYE) agar (21), onto CYE or buffered charcoal-yeast extract (BCYE) agar containing antibiotics (Table 1), or onto BCYE agar (48); (ii) passage of concentrated water samples through guinea pigs, followed by inoculation of infected guinea pig tissues into embryonated hen eggs and subsequent plating of infected yolk sac material onto CYE agar $(36,40$, 46); (iii) passage of concentrated water samples through guinea pigs and direct inoculation of infected guinea pig tissue onto CYE agar $(40,46)$; or (iv) filter concentration of environmental water samples, followed by acid buffer treatment $(5,25)$. Strains were cultured and maintained on CYE or $\mathrm{BCYE}$ agar at $36 \pm 1^{\circ} \mathrm{C}$ in air containing $2.5 \% \mathrm{CO}_{2}$.
Cultural and biochemical tests. All strains of the new Legionella species and the type strains of the previously described Legionella species were stained by the Hucker modification of the Gram strain. Flagellum staining was done by the Clark modification of the Leifson method (17) or as described by Kodaka et al. (32), and 24- to 48-hour cultures grown on $\mathrm{CYE}$ agar at $35^{\circ} \mathrm{C}$ were examined for motility by dark-field microscopy. Cultures were plated onto BCYE agar with and without L-cysteine and onto Trypticase soy agar supplemented with 5\% sheep blood. Autofluorescence was measured by excitation at a wavelength region near 366 nm (54) by using a Woods lamp on cultures grown at $36 \pm$ $1^{\circ} \mathrm{C}$ on BCYE agar. Formation of a brown, water-soluble pigment was observed on cultures grown at $35^{\circ} \mathrm{C}$ on tyrosine-containing yeast extract agar (1). Oxidase, catalase, and D-glucose fermentation tests were done as described by Weaver and Feeley (54). Nitrate reduction, gelatin and liquefaction, and urea hydrolysis were tested as described by Orrison et al. (47). Hydrolysis of sodium hippurate was tested by the method of Hébert (26). Beta-lactamase production was assayed by the chromogenic cephalosporin test described by Thornsberry and Kirven (53).

Direct immunofluorescence assays. Formalin-fixed cells of each type strain of the 10 new Legionella species were stained with direct immunofluorescence assay conjugates prepared for the detection of all but one of the previously described species and serogroups (16). Included were conjugates for $L$. pneumophila serogroups 1 through $9, L$. longbeachae serogroups 1 and 2, L. bozemanii, L. micdadei, L. dumoffi, L. gormanii, L. jordanis, L. oakridgensis, L. wadsworthii, L. sainthelensi, and $L$. feeleii. A conjugate for " $L$. anisa" was not tested. The strains were also tested with 
conjugates prepared for the following three new species described in this study: Legionella spiritensis (strain Mount Saint Helens $9^{\mathrm{T}}[\mathrm{T}=$ type strain $]$ ), Legionella hackeliae (strain Lansing $2^{\mathrm{T}}$ ), and Legionella rubrilucens (strain WA$270 \mathrm{~A}-\mathrm{C} 2^{\mathrm{T}}$ ).

Cellular fatty acids and isoprenoid quinones. The cellular fatty acid compositions and isoprenoid quinone contents were determined as described previously $(43-45)$.

DNA studies. The guanine-plus-cytosine $(G+C)$ contents of Legionella DNAs were determined spectrophometrically by the thermal denaturation method (34). DNAs from Proteus mirabilis $1(40 \mathrm{~mol} \% \mathrm{G}+\mathrm{C})$ and Escherichia coli $\mathrm{K}-12$ $(51 \mathrm{~mol} \% \mathrm{G}+\mathrm{C})$ were used as controls. For the preparation of DNA, strains were grown on BCYE agar in 15 to 30 petri plates $(100$ by $15 \mathrm{~mm})$. The plates were incubated at $35^{\circ} \mathrm{C}$ in an atmosphere containing $2.5 \% \mathrm{CO}_{2}$ until growth was confluent ( 3 to 5 days). The preparation of unlabeled and ${ }^{32} \mathrm{PO}_{4}$-in-vitro-labeled DNA has been described previously, as has the determination of DNA relatedness by the hydroxyapatite method at 60 and $75^{\circ} \mathrm{C}(12)$.

\section{RESULTS}

Legionella and Legionella-like organisms are received for identification at the Centers for Disease Control from state and federal laboratories and from laboratories outside the United States or are obtained in the course of disease outbreaks and environmental studies. These strains are first studied biochemically and serologically. If these methods fail to identify strains as members of recognized Legionella species, the strains are examined for their cellular fatty acid and isoprenoid quinone contents and are characterized further by serological testing and DNA hybridization. The results of these studies allow assignment of such strains to new species or new serogroups in existing species or iden- tification as atypical members of existing species. This experimental protocol was used to characterize all of the presently described species and serogroups in the genus Legionella. The most recent of these are serogroups 7 and 8 in L. pneumophila $(2,4)$, a second serogroup in L. bozemanii (49), and the new species L. feeleii (29), L. sainthelensi (14), and " $L$. anisa"' (Gorman et al., in press).

Similar studies are described here for 14 strains that represent 10 new species in the genus Legionella. These species were first isolated between July 1979 and March 1982. L. hackeliae was isolated from a bronchial biopsy specimen obtained from a woman with pneumonia. All other species were isolated from various water sources (Table 1).

Biochemical studies. The biochemical characteristics of the new Legionella species are shown in Table 2. These characteristics are extremely similar to those of the previously described legionellae. L. spiritensis and perhaps $L$. feeleii are the only new species that hydrolyze hippurate, as most strains of $L$. pneumophila do. The oxidase reaction varied among the new species, as it did among previously described species. Five of the new species autofluoresced when cultures were examined under a Woods light. Three of these, Legionella parisiensis, Legionella cherrii, and Legionella steigerwaltii, exhibited bluish white autofluorescence similar to that observed with $L$. bozemanii, $L$. dumoffi, $L$. gormanii, and " L. anisa." L. rubrilucens and Legionella erythra exhibited red autofluorescence.

Cellular fatty acid and isoprenoid quinone analyses. Like other legionellae, each of the 10 new species contained major amounts of ubiquinones with more than 10 isoprene units in the side chain $(14,30,43)$. The cellular fatty acids of the 10 new species were qualitatively similar to those of the previously described legionellae $(14,15,19,27,42,43,47$;

TABLE 2. Phenotypic characteristics of legionellae ${ }^{u}$

\begin{tabular}{|c|c|c|c|c|c|c|c|c|c|c|c|c|c|c|c|}
\hline Species & $\begin{array}{c}\text { Growth } \\
\text { on } \\
\text { blood } \\
\text { agar }\end{array}$ & $\begin{array}{c}\text { Growth } \\
\text { on } \\
\text { BCYE } \\
\text { agar }\end{array}$ & $\begin{array}{l}\text { Growth } \\
\text { require- } \\
\text { ment } \\
\text { for cys- } \\
\text { teine }\end{array}$ & $\begin{array}{c}\text { Gram } \\
\text { stain }\end{array}$ & $\begin{array}{l}\mathrm{NO}_{3} \\
\mathrm{NO}_{2}\end{array}$ & Urease & $\begin{array}{c}\text { Acid } \\
\text { from D- } \\
\text { glucose }\end{array}$ & Catalase & $\begin{array}{l}\text { Browning } \\
\text { of YE } \\
\text { contain- } \\
\text { ing tyro- } \\
\text { sine }^{b}\end{array}$ & $\mid \begin{array}{c}\text { Gelatin } \\
\text { lique- } \\
\text { faction }\end{array}$ & $\begin{array}{l}\text { Hippurate } \\
\text { hydrolysis }\end{array}$ & Motility & Oxidase & $\begin{array}{c}\text { Beta-lac- } \\
\text { tamase }\end{array}$ & $\begin{array}{l}\text { Auto- } \\
\text { fluores- } \\
\text { cence }\end{array}$ \\
\hline L. pneumophila & $-c$ & + & + & - & - & - & - & + & + & + & + & + & + or $+1-$ & + & - \\
\hline L. feeleii & - & + & + & - & - & - & - & + & $+(w)$ & - & $+1-$ & + & - & - & - \\
\hline L. spiritensis & - & + & + & - & - & - & - & + & + & + & $+(w)$ & + & + & + & - \\
\hline L. longbeachae & - & + & + & - & - & - & - & + & + & + & - & + & + & $+1-$ & - \\
\hline L. jordanis & - & + & + & - & - & - & - & + & + & + & - & + & + & + & - \\
\hline L. oakridgensis & - & + & $+^{d}$ & - & - & - & - & + & + & + & - & - & - & $+(w)$ & - \\
\hline L. wadsworthii & - & + & + & - & - & - & - & + & - & + & - & + & - & + & - \\
\hline L. sainthelensi & - & + & + & - & - & - & - & + & + & + & - & + & + & + & - \\
\hline L. hackeliae & - & + & + & - & - & - & - & $+(w)$ & + & + & - & + & + & + & - \\
\hline L. maceachernii & - & + & + & - & - & - & - & + & + & + & - & + & + & - & - \\
\hline L. jamestowniensis & - & + & + & - & - & - & - & + & + & + & - & + & - & + & - \\
\hline L. santicrucis & - & + & + & - & - & - & - & + & + & + & - & + & + & + & - \\
\hline L. micdadei & - & + & + & - & - & - & - & + & - & - & - & + & + & - & - \\
\hline L. dumoffii & - & + & + & - & - & - & - & + & $+e$ & + & - & + & - & + & $+(\mathrm{BW})$ \\
\hline L. gormanii & - & + & + & - & - & - & - & + & + & + & - & + & - & + & $+(\mathrm{BW})$ \\
\hline "L. anisa" & - & + & + & - & - & - & - & + & + & + & - & + & + & + & $+(\mathrm{BW})^{f}$ \\
\hline L. cherrii & - & + & + & - & - & - & - & + & + & + & - & + & - & + & $+(\mathrm{BW})$ \\
\hline L. steigerwaltii & - & + & + & - & - & - & - & + & + & + & - & + & - & + & $+(\mathrm{BW})$ \\
\hline L. parisiensis & - & + & + & - & - & - & - & + & + & + & - & + & + & + & $+(\mathrm{BW})$ \\
\hline L. rubrilucens & - & + & + & - & - & - & - & + & + & + & - & + & - & + & $+(\mathbf{R})$ \\
\hline L. erythra & - & + & + & - & - & - & - & + & + & + & - & + & + & + & $+(\mathrm{R})$ \\
\hline
\end{tabular}

${ }^{a}$ Data for previously described species were taken from the following references: $9,14,15,19,26-29,33,37,41,47,52-54$; Gorman et al., in press.

${ }^{b}$ YE, Charcoal-treated yeast extract agar.

$c+$, Positive; - , negative; $+(w)$, weak reaction; $+/-$, Weakly or not always positive; $(B W)$, bluish white autofluorescence; (R), red autofluorescence.

${ }^{d}$ Strains of this species adapt to grow in the absence of cysteine, but require cysteine when first isolated.

e A strain of $L$. dumoffii did not produce a diffusable brown pigment (P. H. Edelstein, personal communication),

$f$ One of the seven known "L. anisa" strains does not autofluoresce (Gorman et al., in press). 
Gorman et al., in press). With the exception of L. erythra, all of the new species contained major amounts of branchedchain fatty acids. The cellular fatty acids and ubiquinones of these species will be described separately in detail (C. W. Moss, manuscript in preparation).

Characterization by direct immunofluorescence staining. Conjugates prepared for $L$. spiritensis, $L$. hackeliae, and $L$. rubrilucens stained their respective type strains (strains Mount Saint Helens 9, Lansing 2, and WA-270A-C2) with $4+$ fluorescence intensity, and cross-reactions with other Legionella species were not observed. Some cross-reactions were observed between conjugates for previously characterized legionellae and antigens prepared from type strains of the 10 new species. L. parisiensis stained weakly with conjugates for $L$. bozemanii (fluorescence intensity, $1+$ ), $L$. micdadei $(1+)$, and $L$. jordanis $(2+)$; Legionella santicrucis stained $3+$ with the L. longbeachae serogroup 1 conjugate. The only additional cross-reactions observed when undiluted conjugates $(10 \mathrm{mg}$ of immunoglobulin $\mathrm{G}$ per $\mathrm{ml}$ of conjugate) were used were between $L$. santicrucis antigen and $L$. sainthelensi conjugate $(2+)$ and between Legionella maceachernii antigen and $L$. micdadei conjugate ( $3+)$. The weak cross-reactions of $L$. parisiensis antigen with $L$. bozemanii and $L$. jordanis became $4+$ when undiluted conjugates were used. Antigenic relationships were noted previously for L. bozemanii and $L$. jordanis (15) and for L. longbeachae and $L$. sainthelensi (14). Comprehensive antigenic analyses of the new species are in progress (H.W.W.).

DNA studies. DNAs from all of the new type strains representing Legionella species were labeled in vitro with ${ }^{32} \mathrm{PO}_{4}$. DNA hybridization reactions were done to establish the uniqueness of each species and to determine its relatedness to all other Legionella species (Table 3). Type strains of all species, as well as additional strains of the new species, where available, were used as sources of the unlabeled DNAs in these experiments.

Legionella jamestowniensis was 1 to $17 \%$ related to other Legionella species. L. hackeliae was 3 to $22 \%$ related to other species, with 14 to $17 \%$ relatedness (in reciprocal reactions) to $L$. jamestowniensis and $22 \%$ relatedness to $L$. cherrii. L. maceachernii consisted of two strains that were essentially identical; its closest relative $(23 \%)$ was $L$. micdadei. $L$. spiritensis was most related to $L$. rubrilucens (34\%), a red-autofluorescing species, and was 19 to $21 \%$ related to a number of species, including $L$. erythra, the other red-autofluorescing species.

The two red-autofluorescing species, L. rubrilucens and $L$. erythra, were 59 to $62 \%$ interrelated, with 9.0 to $9.5 \%$ divergence in related sequences, and 27 to $34 \%$ related in $75^{\circ} \mathrm{C}$ reactions; their closest relative was $L$. spiritensis $(34$ and $20 \%$ related, respectively).

The three bluish white-autofluorescing species, L. parisiensis, $L$. cherrii, and $L$. steigerwaltii, were substantially related to one another and to the other bluish white-autofluorescing species. L. parisiensis was 57 to $67 \%$ related to four strains of $L$. bozemanii, with 7.5 to $9.0 \%$ divergence in related sequences, and 26 to $39 \%$ related in $75^{\circ} \mathrm{C}$ reactions. $L$. parisiensis was 50 to $59 \%$ related to three " $L$. anisa" strains and 22 to $40 \%$ related to the other bluish white-autofluorescing species. The level of relatedness of $L$. parisiensis to species that do not exhibit bluish white autofluorescence was highest with $L$. wadsworthii $(37 \%)$. The four strains of $L$. cherrii were $94 \%$ or more related at optimal $\left(60^{\circ} \mathrm{C}\right)$ and stringent $\left(75^{\circ} \mathrm{C}\right)$ reassociation criteria and exhibited $0.0 \%$ to $0.5 \%$ divergence in related sequences. $L$. cherrii was highly related to $L$. steigerwaltii $(67 \%), L$. dumoffii
(57\%), "L. anisa" (56\%), L. bozemanii (51\%), and $L$. gormanii $(47 \%)$. The level of relatedness of $L$. cherrii to another bluish white-autofluorescing species, $L$. parisiensis, was $24 \%$. L. cherrii was 6 to 35\% related to other legionellae. L. steigerwaltii was 32 to $54 \%$ related to the other bluish white-autofluorescing species and 31 to $34 \%$ related to the non-autofluorescing species $L$. santicrusis, $L$. wadsworthii, and $L$. sainthelensi.

L. santicrucis was closely related to $L$. sainthelensi $(64 \%$ at $60^{\circ} \mathrm{C}, 23 \%$ at $75^{\circ} \mathrm{C}$ ) and was $38 \%$ related to $L$. longbeachae.

It is clear that each of the 10 new Legionella species, as well as the 12 previously described species, can be separated from all other legionellae on the basis of DNA relatedness. The strains of any one species showed $70 \%$ or more relatedness in $60^{\circ} \mathrm{C}$ reactions, less than $4 \%$ divergence in related sequences, and more than $60 \%$ relatedness in $75^{\circ} \mathrm{C}$ reactions.

The 12 previously described Legionella species had $\mathrm{G}+\mathrm{C}$ contents of 39 to $46 \mathrm{~mol} \%$ (Table 1), and 8 of the 10 new species had $\mathrm{G}+\mathrm{C}$ contents of 38 to $46 \mathrm{~mol} \%$ (Table 1 ). The two red-autofluorescing species, $L$. parisiensis and $L$. erythra, had $\mathrm{G}+\mathrm{C}$ contents of 52 and $51 \mathrm{~mol} \%$, respectively (Table 1).

\section{DISCUSSION}

Brown and colleagues proposed the formation of the following three genera from the first five species of Legionella $(13,24)$ : Legionella (with only one species, L. pneumophila), Tatlockia (with Tatlockia micdadei), and Fluoribacter (with Fluoribacter bozemanii, Fluoribacter dumoffi, and Fluoribacter gormanii). We have opposed this proposal on several grounds. First, there is not a genetic definition for a genus. If there were one, it is doubtful that the relatedness values among the three species that were placed in Fluoribacter would fit the genetic definition of a genus. The level of relatedness between Fluoribacter species is as low as $12 \%$, with as much as $25 \%$ relatedness between these species and $L$. pneumophila in our studies $(9,10,21,41)$. In the studies of Brown et al., Fluoribacter species showed as little as $4 \%$ interrelatedness, compared with values of up to $14 \%$ with $L$. pneumophila and up to $10 \%$ with $L$. micdadei $(13,24)$.

If we consider the creation of additional genera for not only the first 5 species but all 22 Legionella species, the problems are compounded (Table 4). At a $40 \%$ relatedness level, there are 14 genera; one contains the 7 bluish whiteautofluorescing species, one contains the 2 red-autofluorescing species, 1 contains $L$. sainthelensi and $L$. santicrucis, and 11 genera each contain a single species. This $40 \%$ criterion ignores the fact that several of the species in the bluish white-autofluorescing group are not $40 \%$ related to all of the other species in the group and the fact that $L$. wadsworthii is as much as $37 \%$ related to members of this group.

At a $30 \%$ relatedness level there would be 11 genera. $L$. spiritensis (which does not autofluoresce) is added to the red-autofluorescing group. L. wadsworthii (which does not autofluoresce) is added to the bluish white-autofluorescing group. $L$. santicrucis and $L$. sainthelensi (which do not autofluoresce) are also more than $30 \%$ related to the bluish white-autofluorescing group, but they also form their own group, along with $L$. longbeachae and two of the bluish white-autofluorescing species, $L$. steigerwaltii and $L$. cherrii. Eight additional genera would contain single species.

At a $25 \%$ relatedness level, as advocated by Brown and colleagues $(13,24)$, there would be nine genera. The red-au- 
tofluorescing group remains the same as at the $30 \%$ level, the bluish white-autofluorescing group and the $L$. sainthelensi group merge into a single genus, a new group is formed (at a relatedness level of $23 \%$ ) from $L$. micdade $i$ and $L$. maceachernii, and six genera contain single species.

Even if one could define and separate these genetic genera by phenotypic tests, none of these alternatives is appealing. The fact is that legionellae can be identified to species only by serogrouping or DNA hybridization. With a combination of biochemical tests and analyses of cellular fatty acids and ubiquinones, one can define legionellae at the family level and form species groups, but cannot identify individual species.

Very few strains of most Legionella species have been examined phenotypically; in many species only one or a few strains have been isolated. Even with this limited sample, there is phenotypic variation. Not all strains of L. pneumophila hydrolyze hippurate (26), one $L$. dumoffii strain does not produce brown pigment (P. H. Edelstein, personal communication), one strain of " $L$. anisa" does not exhibit bluish white autofluorescence (Gorman et al, in press), and the $L$. feeleii strain has been reported to hydrolyze hippurate (29) but did not do so when retested as part of this study (Table 2). Furthermore, grouping of species on the basis of DNA relatedness creates problems due to mixed phenotypes. L. wadsworthii, L. santicrucis, $L$. sainthelensi, and $L$. longbeachae do not autofluoresce, but depending on the DNA criteria used to define a genus, they could be grouped with the bluish white-autofluorescing species. Similarly, $L$. spiritensis could be grouped with the red-autofluorescing species.

There is a good definition for strains of a genetic species (70\% or more relatedness in reactions done at optimal criteria for DNA reassociation, $6 \%$ or less divergence in related sequences, and at least $55 \%$ relatedness in reactions done at a supraoptimal [stringent] criterion for DNA reassociation [7]). It is our opinion that although a species reflects evolutionary divergence, a genus is a man-made division that should consist of a group of phenotypically similar species that must be differentiated from one another at the microbiology bench. If genetic and phenotypic similarities are not in agreement, then a genus based on phenotype is preferable and more practical to taxonomists and to all microbiologists than a genus based on genetic relatedness. Legionella is certainly a good phenotypic genus. All species are isolated by the same methods and cultivated on the same media. They have similar biochemical profiles and are easily differentiated from other gram-negative bacteria by their unique fatty acid composition and isoprenoid quinone content. When motile, they have a common flagellar antigen. Many species exhibit cross-reactions between their somatic antigens. All species that have been isolated from humans cause the same disease, and the same treatment regimen is used against all species known to cause human diseases. For all of the above reasons it would be of little, if any, benefit to create additional genera in the family Legionellaceae at this time.

Taxonomic proposals. Nomenclatural proposals are given below for 10 new Legionella species; 3 of the 10 new species are named after people who are coauthors of this paper. In all of these cases, the names were arrived at by D.J.B. and G.W.G. without the knowledge of the people for whom the species are named.

The 10 new species conform to the definition of the family Legionellaceae and to the definition of the genus Legionella (8), except that the range of $\mathrm{G}+\mathrm{C}$ contents within the family and the genus is now 38 to $52 \mathrm{~mol} \%$. All of the species are gram-negative, catalase-positive rods that grow on BCYE agar but not on blood agar and require cysteine for growth. They are motile by means of one to a few polar, subpolar, or lateral flagella. They do not produce acid from D-glucose, reduce nitrates, or contain a urease. They liquefy gelatin, and they form a soluble brown pigment on yeast extract agar that contains tyrosine. Unless noted below, the new species do not hydrolyze hippurate, and they do produce beta-lactamase. The sources of the strains of each species are given in Table 1, and their DNA relatedness relationships are shown in Table 3. Other characteristics of the 10 new species are given below and in the tables and text.

Legionella species 13: Legionella maceachernii. Legionella maceachernii sp. nov. (mac. kath'er. ni. i. N. L. gen. n. maceachernii in honor of Harold V. McEachern who has provided dedicated laboratory support from the earliest studies on legionellae to the present and as a tribute to the dozens of dedicated laboratory personnel who have contributed so much to our knowledge of legionellae) is an oxidasepositive organism that does not autofluoresce or produce beta-lactamase. Its other biochemical reactions are typical for legionellae, as described above. The type strain of $L$. maceachernii is strain PX-1-G2-E2 ( = ATCC 35300), which has a $\mathrm{G}+\mathrm{C}$ content of $43 \mathrm{~mol} \%$.

Legionella species 14: Legionella jamestowniensis. Legionella jamestowniensis sp. nov. (james. town' i. en. sis. N. L. fem. adj. jamestowniensis coming from Jamestown, N.Y.) is an oxidase-negative organism that does not autofluoresce. Its other biochemical reactions are typical for legionellae, as described above. The type strain is strain JA-26-G1-E2 (= ATCC 35298), which has a $\mathrm{G}+\mathrm{C}$ content of $42 \mathrm{~mol} \%$.

Legionella species 15: Legionella rubrilucens. Legionella rubrilucens sp. nov. (ru. bri. lu' cens. N. L. part adj. rubrilucens red-shining, referring to red autofluorescence) is an oxidase-negative organism that autofluoresces red. Its other biochemical reactions are typical for legionellae, as described above. The type strain is strain WA-270A-C2 (= ATCC 35304), which has a $\mathrm{G}+\mathrm{C}$ content of $52 \mathrm{~mol} \%$.

Legionella species 16: Legionella erythra. Legionella erythra sp. nov. (e. ry' thra. Gr. fem. adj. erythra red, referring to red autofluorescence) is an oxidase-positive organism that autofluoresces red. Its other biochemical reactions are typical for legionellae, as described above. The type strain is strain SE-32A-C8 (= ATCC 35303), which has a $\mathrm{G}+\mathrm{C}$ content of $51 \mathrm{~mol} \%$.

Legionella species 17: Legionella hackeliae. Legionella hackeliae sp. nov. (hack' el. i. ae. N. L. gen. n. hackeliae in honor of Meredith Hackel, who isolated it, and in tribute to the many state public health and clinical laboratory workers who have isolated new strains of legionellae) is an oxidasepositive organism that does not autofluoresce. Its other biochemical reactions are typical for legionellae, as described above. The type strain is strain Lansing 2 (= ATCC 35250 ), which has a $G+C$ content of $40 \mathrm{~mol} \%$.

Legionella species 18: Legionella spiritensis. Legionella spiritensis sp. nov. (spir' it. en. sis. N. L. fem. adj. spiritensis coming from Spirit Lake) is an oxidase-positive organism that gives a weakly positive reaction in the test for hydrolysis of hippurate and does not autofluoresce. Its other biochemical reactions are typical for legionellae, as described above. The type strain is strain Mount Saint Helens 9 (= ATCC 35249), which has a G $+\mathrm{C}$ content of $46 \mathrm{~mol} \%$.

Legionella species 19: Legionella parisiensis. Legionella parisiensis sp. nov. (pa. ri. si. en' sis. N. L. fem. adj. parisiensis coming from Paris, France) is an oxidase-positive 
INT. J. SYST. BACTERIOL.

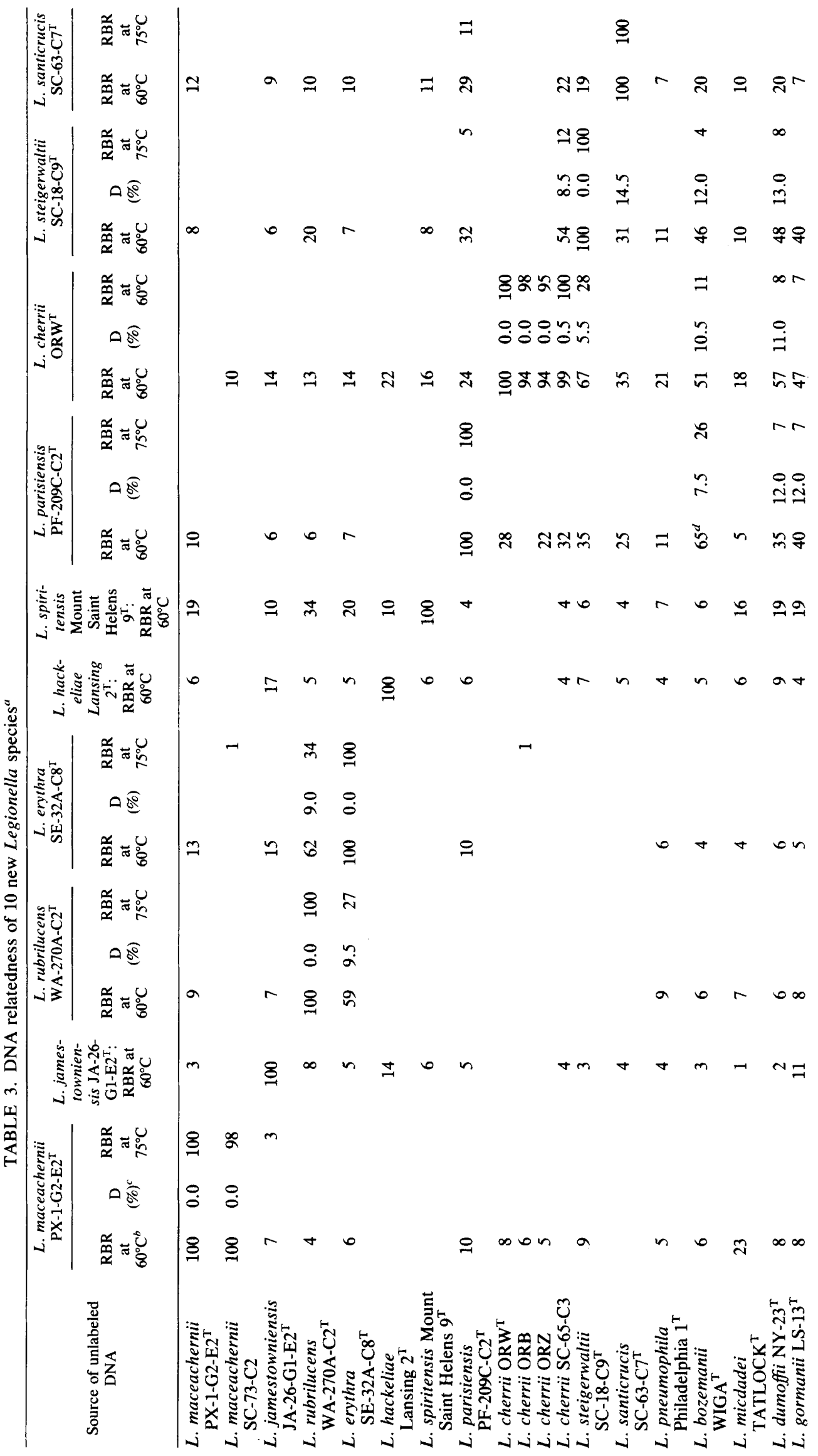




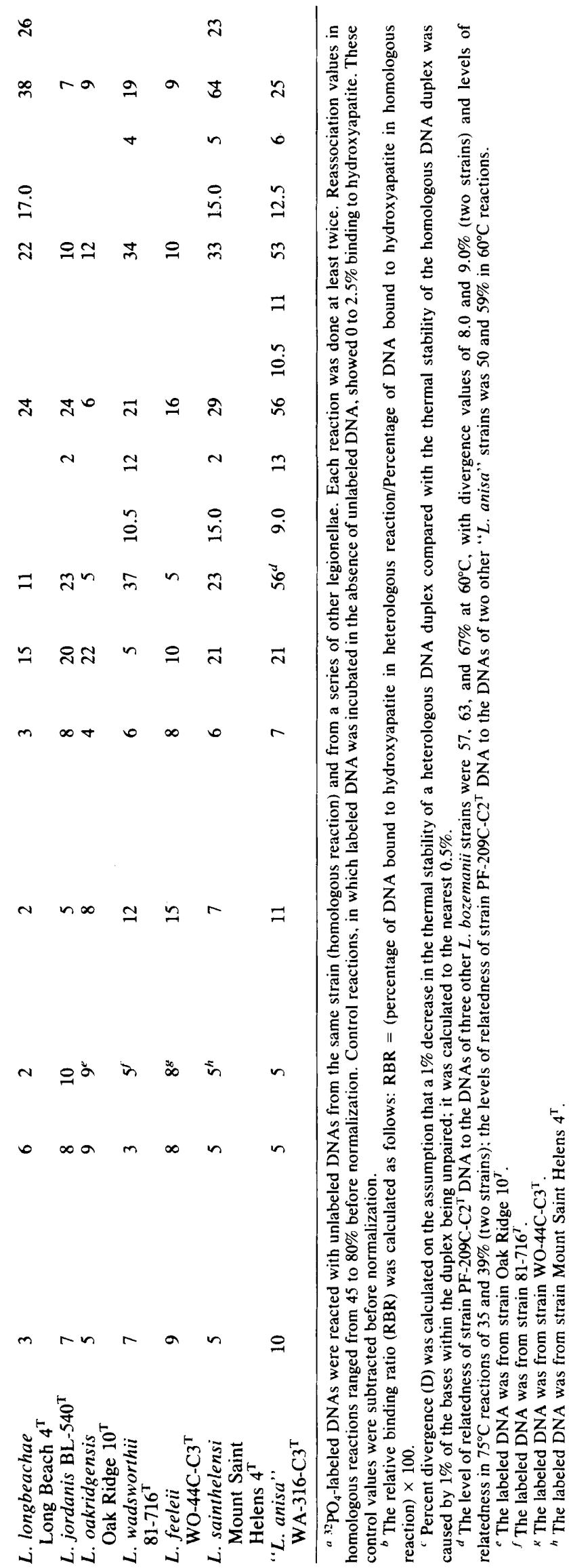

TABLE 4. Possible division of legionellae into multiple genera on the basis of DNA relatedness levels

\begin{tabular}{|c|c|c|}
\hline $\begin{array}{l}\text { Level of } \\
\text { related- } \\
\text { ness }(\%)\end{array}$ & $\begin{array}{l}\text { Genus } \\
\text { designa- } \\
\text { tion }\end{array}$ & Species included \\
\hline \multirow[t]{14}{*}{40} & I & L. rubrilucens, $L$. erythra \\
\hline & II & $\begin{array}{l}\text { L. parisiensis, L. cherrii, L. steigerwaltii, } \\
\text { L. bozemanii, L. dumoffi, } \\
\text { L. gormanii, "L. anisa", }\end{array}$ \\
\hline & III & L. sainthelensi, L. santicrucis \\
\hline & IV & L. spiritensis \\
\hline & $\mathrm{V}$ & L. wadsworthii \\
\hline & VI & L. longbeachae \\
\hline & VII & L. micdadei \\
\hline & VIII & L. maceachernii \\
\hline & IX & L. pneumophila \\
\hline & $X$ & L. jordanis \\
\hline & XI & L. oakridgensis \\
\hline & XII & L. feeleii \\
\hline & XIII & L. jamestowniensis \\
\hline & XIV & L. hackeliae \\
\hline \multirow[t]{11}{*}{30} & I & L. rubrilucens, L. erythra, L. spiritensis \\
\hline & II & $\begin{array}{l}\text { L. parisiensis, L. cherrii, L. steigerwaltii, } \\
\text { L. bozemanii, L. dumoffi, L. gormanii, } \\
\text { "L. anisa," L. wadsworthii } \\
\text { (L. santicrucis, L. sainthelensi) }\end{array}$ \\
\hline & III & $\begin{array}{l}\text { L. sainthelensi, L. santicrucis, } \\
\text { L. longbeachae (L. steigerwaltii, } \\
\text { L. cherrii) }\end{array}$ \\
\hline & IV & L. micdadei \\
\hline & $\mathrm{V}$ & L. maceachernii \\
\hline & VI & L. pneumophila \\
\hline & VII & L. jordanis \\
\hline & VIII & L. oakridgensis \\
\hline & IX & L. feeleii \\
\hline & $\mathrm{X}$ & L. jamestowniensis \\
\hline & $\mathrm{XI}$ & L. hackeliae \\
\hline \multirow[t]{9}{*}{25} & 1 & L. rubrilucens, $L$. erythra, L. spiritensis, \\
\hline & II & $\begin{array}{l}\text { L. parisiensis, } L . \text { cherrii, L. steigerwaltii, } \\
\text { L. bozemanii, L. dumoffi, L. gormanii, } \\
\text { "L. anisa," L. wadsworthii, } \\
\text { L. santicrucis, L. sainthelensi, } \\
\text { L. longbeachae }\end{array}$ \\
\hline & III & L. micdadei, L. maceachernii \\
\hline & IV & L. pneumophila \\
\hline & V & L. jordanis \\
\hline & VI & L. oakridgensis \\
\hline & VII & L. feeleii \\
\hline & VIII & L. jamestowniensis \\
\hline & IX & L. hackeliae \\
\hline
\end{tabular}

"At this criterion for genus formation the species in parentheses are at or just below the genus level.

organism that autofluoresces bluish white. Its other biochemical reactions are typical for legionellae, as described above. The type strain is strain PF-209C-C2 (= ATCC 35299) which has a $\mathrm{G}+\mathrm{C}$ content of $42 \mathrm{~mol} \%$.

Legionella species 20: Legionella cherrii. Legionella cherrii sp. nov. (cher' ri. i. N. L. gen. n. cherrii in honor of William B. Cherry for his many pioneering contributions to our knowledge of legionellae) is an oxidase-negative organism that autofluoresces bluish white. Its other biochemical reactions are typical for legionellae, as described above. The type strain is strain ORW (= ATCC 35252), which has a $\mathrm{G}+\mathrm{C}$ content of $40 \mathrm{~mol} \%$.

Legionella species 21: Legionella steigerwaltii. Legionella steigerwaltii sp. nov. (stei. ger. walt' i. i. N. L. gen. n. steigerwaltii in honor of Arnold G. Steigerwalt, who did the definitive experiments to classify all 22 known Legionella 
species) is an oxidase-negative organism that autofluoresces bluish white. Its other biochemical reactions are typical for legionellae, as described above. The type strain is strain SC-18-C9 ( = ATCC 35302), which has a G +C content of 40 mol\%.

Legionella species 22: Legianella santicrucis. Legionella santicrucis sp. nov. (san. ti. cru' cis. N. L. gen. n. santicrucis of Santa Crux, Latin name of St. Croix, Virgin Islands) is an oxidase-positive organism that does not autofluoresce. Its other biochemical reactions are typical for legionellae, as described above. The type strain is strain SC-63-C7 ( = ATCC 35301), which has a G +C content of 38 $\mathrm{mol} \%$.

\section{ACKNOWLEDGMENTS}

We are indebted to C. W. Moss and M. A. Lambert at the Centers for Disease Control for doing cellular fatty acid and isoprenoid quinone analyses and to Thomas Ozro MacAdoo, Department of Languages and Literatures, Virginia Polytechnic Institute and State University, Blacksburg, for his expert advice on latinization of the species names.

\section{LITERATURE CITED}

1. Baine, W. B., J. K. Rasheed, J. C. Feeley, G. W. Gorman, and L. E. Casida, Jr. 1978. Effect of supplemental L-tyrosine on pigment production in cultures of the Legionnaires' disease bacterium. Curr. Microbiol. 1:93-94.

2. Bibb, W. F., P. M. Arnow, D. L. Dellinger, and S. R. Perryman. 1983. Isolation and characterization of a seventh serogroup of Legionella pneumophila. J. Clin. Microbiol. 17:346-348.

3. Bibb, W. F., R. J. Sorg, B. M. Thomason, M. Hicklin, A. G. Steigerwalt, D. J. Brenner, and M. R. Wulf. 1981. Recognition of a second serogroup of Legionella longbeachae. J. Clin. Microbiol. 14:674-677.

4. Bissett, M. L., J. O. Lee, and D. S. Lindquist. 1983. A new serogroup of Legionella pneumophila: serogroup 8. J. Clin. Microbiol. 17:887-891.

5. Bopp, S., J. W. Sumner, G. K. Morris, and J. G. Wells. 1981 Isolation of Legionella spp. from environmental water samples by low-pH treatment and use of selective medium. J. Clin. Microbiol. 13:714-719.

6. Bozeman, F. M., J. W. Humphries, and J. M. Campbell. 1968. A new group of rickettsia-like agents recovered from guinea pigs. Acta Virol. (English ed.) 12:87-93.

7. Brenner, D. J. 1981. Introduction to the family Enterobacteriaceae, p. 1105-1127. In M. P. Starr, H. Stolp, H. G. Trüper, A. Balows, and H. G. Schlegel (ed.), The prokaryotes. SpringerVerlag, New York.

8. Brenner, D. J., J. C. Feeley, and R. E. Weaver. 1984. Family VII. Legionellaceae Brenner, Sțeigerwalt, and McDade 1979 , 658 , p. 279-288. In N. R. Kreig and J. G. Holt (ed.), Bergey's manual of systematic bacteriology, vol. 1. The Williams \& Wilkins Co., Baltimore.

9. Brenner, D. J., A. G. Steigerwalt, G. W. Gorman, R. E. Weaver, J. C. Feeley, L. G. Cordes, H. W. Wilkinson, C. Patton, B. M. Thomason, and K. R. Lewallen Sasseville. 1980. Legionella bozemanii sp. nov. and Legionella dumoffii sp. nov.: classification of two additional species of Legionella associated with human pneumonia. Curr. Microbiol. 4:111-116.

10. Brenner, D. J., A. G. Steigerwalt, and J. E. McDade. 1979 Classification of the Legionnaires' disease bacterium: Legionella pneumophila, genus novum, species nova of the family Legionellaceae, familia nova. Ann. Intern. Med. 90:656-658.

11. Brenner, D. J., A. G. Steigerwalt, S. Pohl, H. Behrens, W. Mannheim, and R. E. Weaver. 1981. Lack of relatedness of Legionella pneumophila to Cytophagaceae, "Pasteurellaceae", and Kingella. Int. S. Syst. Bacteriol. 31:89-90.

12. Brenner, D. J., A. G. Steigerwalt, R. E. Weaver, J. E. McDade, and J. C. Feeley, and M. Mandel. 1978. Classification of the Legionnaires' disease bacterium: an interim report. Curr. Mi- crobiol. 1:71-75.

13. Brown, A., G. M. Garrity, and R. M. Vickers. 1981. Fluoribacter dumoffii (Brenner et al.) comb. nov. and Fluoribacter gormanii (Morris et al.) comb. nov. Int. J. Syst. Bacteriol. 31:111-115.

14. Campbell, J., W. F. Bibb, M. A. Lambert, S. Eng, A. G. Steigerwalt, J. Allard, C. W. Moss, and D. J. Brenner. 1984. Legionella sainthelensi: a new species of Legionella isolated from water near Mt. St. Helens. Appl. Environ. Microbiol. 47:369-373.

15. Cherry, W. B., G. W. Gorman, L. H. Orrison, C. W. Moss, A. G. Steigerwalt, H. W. Wilkinson, S. E. Johnson, R. M. McKinney, and D. J. Brenner. 1982. Legionella jordanis: a new species of Legionella isolated from water and sewage. J. Clin. Microbiol. 15:290-297.

16. Cherry, W. B., and R. M. McKinney. 1979. Detection of Legionnaires' disease bacteria in clinical specimens by direct immunofluorescence, p. 91-103. In G. L. Jones and G. A. Hébert (ed.), "Legionnaires'," the disease, the bacterium and methodology. Centers for Disease Control, Atlanta.

17. Clark, W. A. 1976. A simplified Leifson flagella stain. J. Clin. Microbiol. 3:632-634.

18. Cordes, L. G., H. W. Wilkinson, G. W. Gorman, B. J. Fikes, and D. W. Fraser. 1979. Atypical Legionella-like organisms: fastidious water-associated bacteria pathogenic for man. Lancet ii: $927-930$.

19. Edelstein, P. H., D. J. Brenner, C. W. Moss, A. G. Steigerwalt, E. M. Francis, and W. L. George. 1982. Legionella wadsworthii species nova: a cause of human pneumonia. Ann. Intern. Med. 97:809-813.

20. England, A. C., III, R. M. McKinney, P. Skaliy, and G. W. Gorman. 1980. A fifth serogroup of Legionella pneumophila. Ann. Intern. Med. 93:58-59.

21. Feeley, J. C., R. J. Gibson, G. W. Gorman, N. C. Langford, J. K. Rasheed, D. C. Mackel, and W. B. Baine. 1979. Charcoalyeast extract agar: primary isolation medium for Legionella pneumophila. J. Clin. Microbiol. 10:436-441.

22. Fraser, D. W., and J. E. McDade. 1979. Legionellosis. Sci. Am. 241:82-99.

23. Fraser, D. W., T. F. Tsai, W. Orenstein, W. E. Parkin, H. J. Beecham, R. G. Sharrer, J. Harris, G. F. Mallison, S. M. Martin, J. E. McDade, C. C. Shepard, P. S. Brachman, and the Field Investigation Team. 1977. Legionnaires' disease: description of an epidemic. N. Engl. J. Med. 297:1189-1197.

24. Garrity, G. M.; A. Brown, and R. M. Vickers. 1980. Tatlockia and Fluoribacter: two new genera of organisms resembling Legionella pneumophila. Int. J. Syst. Bacteriol. 30:609-614.

25. Gorman, G. W., J. M. Barbaree, and J. C. Feeley. 1983 Procedures for the recovery of Legionella from water. Centers for Disease Control, Atlanta.

26. Hébert, G. A. 1981. Hippurate hydrolysis by Legionella pneumophila. J. Clin. Microbiol. 13:240-242.

27. Hébert, G. A., C. W. Moss, L. K. McDougal, F. M. Bozeman, R. M. McKinney, and D. J. Brenner. 1980. The rickettsia-like organisms TATLOCK (1943) and HEBA (1959): bacteria phenotypically similar to but genetically distinct from Legionella pneumophila and the WIGA bacterium. Ann. Intern. Med. 92:45-52.

28. Hebert, G. A., A. G. Steigerwalt, and D. J. Brenner. 1980. Legionella micdadei species nova: classification of a third species of Legionella associated with human pneumonia. Curr. Microbiol. 3:255-257.

29. Herwaldt, L. A., G. W. Gorman, T. McGrath, S. Toma, B. Brake, A. W. Hightower, J. Jones, A. L. Reingold, P. A. Boxer, P. W. Tang, C. W. Moss, H. Wilkinson, D. J. Brenner, A. G. Steigerwalt, and C. V. Broome. 1984. A new Legionella species, Legionella feeleii species nova, causes Pontiac fever in an automobile plant. Ann. Intern. Med. 84:333-338.

30. Karr, D. E., W. F. Bibb, and C. W. Moss. 1982. Isoprenoid quinones of the genus Legionella. J. Clin. Microbiol. 15:1044-1048.

31. Kaufmann, A. F., J. E. McDade, C. M. Patton, J. V. Bennett, P. Skaliy, J. C. Feeley, D. C. Anderson, M. E. Potter, V. F. 
Newhouse, M. B. Gregg, and P. S. Brachman. 1981. Pontiac fever: isolation of the etiologic agent (Legionella pneumophila) and demonstration of its mode of transmission. Am. J. Epidemiol. 114:337-347.

32. Kodaka, H., A. Y. Amfield, G. L. Lombard, and V. R. Dowell, Jr. 1982. Practical procedure for demonstrating bacterial flagella J. Clin. Microbiol. 16:948-952.

33. Lewallen, K. R., R. M. McKinney, D. J. Brenner, C. W. Moss, D. H. Dail, B. M. Thomason, and R. A. Bright. 1979. A newly identified bacterium phenotypically resembling, but genetically distinct from Legionella pneumophila: an isolate in a case of pneumonia. Ann. Intern. Med. 91:831-834.

34. Marmur, J., and P. Doty. 1962. Determination of the base composition of deoxyribonucleic acid from its thermal denaturation temperature. J. Mol. Biol. 5:109-118.

35. McDade, J. E., D. J. Brenner, and F. M. Bozeman. 1979. Legionnaires' disease bacterium isolated in 1947. Ann. Intern. Med. 90:659-661.

36. McDade, J. E., C. C. Shepard, D. W. Fraser, T. R. Tsai, M. A Redus, W. R. Dowdle, and the Laboratory Investigation Team. 1977. Legionnaires' disease: isolation of a bacterium and demonstration of its role in other respiratory disease. N. Engl. J. Med. 297:1197-1203.

37. McKinney, R. M., R. K. Porschen, P. H. Edelstein, M. L. Bissett, P. P. Harris, S. P. Bondell, A. G. Steigerwalt, R. E. Weaver, M. E. Ein, D. S. Linquist, R. S. Kops, and D. J. Brenner. 1981. Legionella longbeachae $\mathrm{sp}$. nov., another etiologic agent of human pneumonia. Ann. Intern. Med. 94:739-743.

38. McKinney, R. M., L. Thacker, P. P. Harris, K. R. Lewallen, G. A. Hébert, P. H. Edelstein, and B. M. Thomason. 1979. Four serogroups of Legionnaires' disease bacteria defined by immunofluorescence. Ann. Intern. Med. 90:621-624.

39. McKinney, R. M., H. M. Wilkinson, H. W. Sommers, B. J. Fikes, K. R. Sasseville, M. M. Yungbluth, and J. S. Wolf. 1980. Legionella pneumophila serogroup six: isolation from cases of legionellosis. identification by immunofluorescence staining and immunologic response to infection. J. Clin. Microbiol. 12:395-401.

40. Morris, G. K., C. M. Patton, J. C. Feeley, S. E. Johnson, G. Gorman, W. T. Martin, P. Skaliy, G. F. Mallison, B. D. Politi, and D. C. Mackel. 1979. Isolation of Legionnaires' disease bacterium from environmental samples. Ann. Intern. Med. 90:664-666.

41. Morris, G. K., A. G. Steigerwalt, J. C. Feeley, E. S. Wong, W. T. Martin, C. M. Patton, and D. J. Brenner. 1980. Legion- ella gormanii sp. nov. J. Clin. Microbiol. 12:718-721.

42. Moss, C. W. 1981. Gas-liquid chromatography as an analytical tool in microbiology. J. Chromatogr. 203:337-347.

43. Moss, C. W., W. F. Bibb, D. E. Karr, G. O. Guerrant, and M. A. Lambert. 1983. Cellular fatty acid composition and ubiquinone content of Legionella feeleii $\mathrm{sp}$. nov. J. Clin. Microbiol. 18:917-919.

44. Moss, C. W., and G. O. Guerrant. 1983. Separation of bacterial ubiquinones using reverse-phase high-performance liquid chromatography. J, Clin. Microbiol. 18:15-17.

45. Moss, C. W., R. E. Weaver, S. B. Dees, and W. B. Cherry. 1977. Cellular fatty acid composition of isolates from Legionnaires disease. J. Clin. Microbiol. 6:140-143.

46. Orrison, L. H., W. B. Cherry, and D. Milan. 1981. Isolation of Legionella from cooling tower water by filtration. Appl. Environ. Microbiol. 41:1202-1205.

47. Orrison, L. H., W. B. Cherry, R. L. Tyndall, C. B. Fliermans, S. B. Gough, M. A. Lambert, W. F. Bibb, L. K. McDougal, and D. J. Brenner. 1983. Legionella oakridgensis: an unusual new species isolated from cooling tower water. Appl. Environ. Microbiol. 45:536-545.

48. Pasculle, A. W., J. C. Feeley, R. J. Gibson, L. G. Cordes, R. L. Myerowitz, C. M. Patton, G. W. Gorman, C. L. Carmack, J. W. Ezzell, and J. N. Dowling. 1980. Pittsburgh pneumonia agent: direct isolation from human lung tissue. J. Infect. Dis. 141:727-732

49. Tang, P. W., S. Toma, C. W. Moss, A. G. Steigerwalt, T. G. Colligan, and D. J. Brenner. 1984. Legionella bozemanii serogroup 2: a new etiologic agent. J. Clin. Microbiol. 19:30-33.

50. Tatlock, H. 1944. A rickettsia-like organism recoverd from guinea pigs. Proc. Soc. Exp. Biol. Med. 57:95-99.

51. Thacker, W. L., H. W. Wilkinson, and R. F. Benson. 1983 Comparison of slide agglutination test and direct immunofluorescence assay for identification of Legionella isolates. J. Clin. Microbiol. 18:1113-1118.

52. Thomason, B. M., F. W. Chandler, and D. G. Hollis. 1979 Flagella on Legionnaries' disease bacteria: an interim report. Ann. Intern. Med. 91:224-226.

53. Thornsberry, C., and L. A. Kirven. 1978. Beta-lactamase of the Legionnaires' bacterium. Curr. Microbiol. 1:51-54.

54. Weaver, R. E., and J. C. Feeley. 1979. Cultural and biochemical characterization of the Legionnaires' disease bacterium, $p$ 20-25. In G. L. Jones and G. A. Hébert (ed.), "Legionnaires',' the disease, the bacterium and methodology. Centers for Disease Control, Atlanta. 